\title{
The use of Imago Dei as a pastoral healing vision against women killings in the South African context
}

\author{
Author: \\ Elijah M. Baloyi ${ }^{1}$ \\ Affiliation: \\ ${ }^{1}$ Department of Practical \\ Theology, University of South \\ Africa, South Africa \\ Correspondence to: \\ Elijah Baloyi \\ Email: \\ baloye@unisa.ac.za \\ Postal address: \\ PO Box 392, UNISA 0003, \\ South Africa

\section{Dates:} \\ Received: 06 Dec. 2011 \\ Accepted: 19 Mar. 2012 \\ Published: 09 May 2012 \\ How to cite this article: \\ Baloyi, E.M., 2012, 'The use \\ of Imago Dei as a pastoral \\ healing vision against women \\ killings in the South African \\ context', Verbum et Ecclesia \\ 33(1), Art. \#703, 6 pages. \\ http://dx.doi.org/10.4102/ \\ ve.v33i1.703
}

C) 2012. The Authors. Licensee: AOSIS OpenJournals. This work is licensed under the Creative Commons Attribution License.
The exploitation and killings of women in South Africa are a concern not only for the government, but also for pastoral caregivers as well. Although the government has introduced institutions like the Commission for Gender Equality with responsibilities to ensure that there is equality between genders, it seems that the supposed patriarchal masculine superiority continues to demonstrate its dominance through the abuse, as well as the killings of women. Assigning women to the status of secondary citizens who are tortured and exposed to genderbased violence is not only unconstitutional, but also biblically wrong, as we can see from the biblical message of the creation of human beings. The goal of this article is to use the premise of 'the image of God' to argue that women also are created in the image of God and hence they are worthy to be treated as such, from sexual harassment, sexual abuse and violence to murder. This is my personal observation as women of this country are being killed by their husbands and boyfriends. This article will use case studies to argue that women (just like men) deserve, as images of God, to live freely without fear of being killed by their husbands and boyfriends for whatever wrongdoing.

\section{Introduction}

Let me introduce my study by quoting Martin and Jung (2002:266):

Feminism means humanism. It means deeply honouring the feminine aspects of the self in both women and men. It means envisioning a society where sexism no longer exists, where opportunities and selfexpression are not limited by one's gender. Everyone becomes valuable in the society, regardless of position, wealth as well as gender in the society. These values promote peace, harmony, freedom, joyousness, kindness, connectedness and relations. (Martin \& Jung 2002:266)

The above-mentioned authors are not South Africans, but the quotation indicates that they have the same struggle as South Africans who are in need of a society which want to see both males and females as equals and give them not only equal treatment, but also value their lives equally. If society wants to undo what in the past has been committed wrongly, this view needs to be shared by churches, communities, workplaces and schools.

This article intends to engage, discuss and denounce, as well as highlight by way of a pastoral caregiver's perspective, some of the issues related to the recent killings resulting from the genderrelated views of individuals. There is still a need to prioritise a study on gender-based violence and killings for a better life for all. Although there might be some people who view the Bible as their reference to promote gender inequality, this article will help to prove from both the biblical and the pastoral point of view that the Creator of people did not intend to create the woman as a secondary citizen, but as an equal partner to man. The discussion, 'that woman are created in the image of God', will play a pivotal role in trying to retain the images as well as the value of women alongside those of the man, not as an inferior person, but as an equal partaker in this life.

I became concerned while reading about the drop in crime reported by the Minister of Police, Nathi Mthethwa, as recorded by Mashaba Sibongile in the Sowetan dated 09 September 2011 (Mashaba 2011:5). The worrying factor was not that a decrease in crimes was reported, but that nothing was said about whether the crime of killing women had declined or not. According to me, the killings of women should also receive attention just like all the other crimes in our country and this motivated me to write this article.

\section{Background}

In the article entitled 'Abuse condemned' the Minister of Women, Children and People with Disabilities together with Deputy Minister of Health were not only embarrassed by the killing of a woman by her husband, but they also indicated the escalation in cases of women and children abuse in South Africa. The two ministers agreed, saying: 'South Africans are seeing an increase 
in abuse against women and children' (Khumalo 2011:5). This account was recorded when the two ministers visited the family of Tsekedi (44) who was allegedly mutilated and murdered by her boyfriend on 19 May 2011 after a lengthy abusive relationship in which the woman filed three cases of abuse with the police which she later withdrew before she was killed. Her body was found in the shack she shared with her boyfriend four days after she disappeared.

In Tshamahansi, a small town outside Mokopane (Limpopo) a 22-year-woman (called Nomsa) went to see her boyfriend. A few days after she left, her body was found dumped behind her boyfriend's toilet. The local community wanted to use the so-called 'mob-justice' to deal with the suspected culprit (boyfriend) but the police intervened. It was expected that the boyfriend should appear in court soon (South African Broadcasting Corporation, Munghana Lonene 2011a). Soon afterwards, the man was arrested.

On 26 May 2011 a constable (police officer) at the Hazyview police station in Mpumalanga allegedly walked into a Mukhuhlu shop where Thembi Shabangu (32) worked, and without saying a word he shot her dead. He later handed himself in at the police station. Thembi had been involved in a three-year-long love affair with this constable (Magagula 2011:2).

In the same vein, on 29 April 2011 the Commission for Gender Equality issued a statement saying:

The commission for Gender Equality strongly condemns the brutal killing and rape of Noxolo Nogwaza. In line with the constitution of the Republic of South Africa, Lesbians, Gays, Bisexuals, transgendered and intersexed people (LGNTI) have the same rights just like everyone else. The continual depicting of irrational homophobic behaviour by some citizens violates the very same core of our constitution that we so much claim to uphold, that of respecting the rights and dignity of others irrespective of their sexual orientation. (South African Goverment Information 2011)

Although this article focuses on the killings of South African women, it is acknowledged that the phenomenon of killing woman is a practice also seen in countries outside South Africa, for example the case in which it is suspected that the British citizen, Dewani killed his own wife as reported in the media (Daily Sun 2011:5).

As a pastoral caregiver I think it would be valuable to research as well as give guidelines on how the killings of women could be eliminated. An incident of rape and attempted murder happened in the province of Mpumalanga. The Pretoria News reported that one woman was raped in the Umhlanga Hotel, and the alleged rapist also stabbed her in the face and hands, and tried to strangle her before he left her close to death. This man had promised the woman a job and took her with him before raping and attempting to kill her (Fourie 2011:3). Rampedi (2010:8), a Sowetan newspaper reporter, in his article entitled 'Woman killed for going on pill' tells the painful story of a woman who was killed by her own husband for taking contraceptives. The incident took place on the farm Kromdraai near Thabazimbi. The two children (of both the deceased and the killer) lacked the financial as well as emotional support of their father for some years as the father was nowhere to be found. When he came back after those years he realised that the woman was using contraceptives to prevent having more children. The husband then 'beat her to death'. It is clear that the man did this because he believed that the woman did not have rights over her body. Although it could be argued and assumed that the woman took the contraceptives because she was unfaithful to her husband; but for this study the focus is on the fact that women are being killed and the concern is that an image of God is being tarnished by these killings.

Jane Mokgosi (2011:4), a Daily Sun reporter indicated that a woman (Lindela Mafunya) was allegedly found murdered on Saturday (20 May 2011) after the angry boyfriend hit her with a bottle during their fight. Her lifeless body was found lying naked in the street with used condoms and a big rock next to it. When the couple had last been seen they had fought in the street, and the boy had forced her to go with him to his place and she had refused. One of the victim's relatives testified: 'The suspect used to beat my aunt every weekend. We told her several times to leave him but she didn't want to listen' (Mokgosi 2011:4). These are just some of the reported cases. There is no doubt that there are many that have not been reported.

My personal interpretation of the above is 'From abuse to killing.' Previously, the violence that was experienced resulted from women being beaten and battered, but now they are even brutally killed by their husbands and boyfriends. Although it is not yet clear why the women were killed, it is becoming clear that gender-related violence is going from bad to worse. There have been a lot of campaigns and voices raised against the abuse and rape of women, but it seems some men, instead of refraining from these abusive tendencies, even kill women. If the society, government and pastoral caregivers take responsibility to address this problem - even the retaliations by mobs, in which people take the law into their own hands and which has become a practice amongst people - would be eliminated. The question is: 'Why are men becoming so hostile and cruel to women?'

'Where am I wrong when I beat my own wife?' This was a question asked by a man who was being questioned by some elders of Driefontein, Piet Retief, in Mpumalanga after having beaten his wife until she was close to death (City Press 18 February 2007:10). This question shows that some men still do not see the killing of women as a serious offence.

During the apartheid era the English singer, Phil Collins said: 'Freedom of life is a fundamental human right, but not in South Africa' (Baloyi 2009:162). Although the constitution of our country protects the right to life of all people living in South Africa, the patriarchal perceptions and mindsets of South African males are not yet liberated, they still view 
women as secondary people who deserve not only to be exploited and abused, but also to be killed.

The very recent incidents mentioned above are not only a threat to the young South African democracy, but they are also an indication that there are still people in the society who degrade and devalue women to second-class human beings. The issue of women being killed by either their husbands or their boyfriends undermines the message of seeing the female gender as God's creation just like the creation of males. The barbaric incidents towards women in our country strongly suggest that there is a continuity of certain males seeing women as mere objects (Baloyi 2009:15).

These gender-based killings make it very difficult, if not impossible, for many women to see themselves as people with a right to life in this part of the continent. Their love and trust are being betrayed by the very people who are supposed to protect them.

\section{Different views of the image of God Homo interior}

Borreson (1986) says:

According to Genesis, human nature as such has been made in the image of God, a nature which exists in both sexes and which does not allow of our setting woman aside when it comes to understanding what the image of God is. With regard to "homo interior", the woman possesses the quality of the image of God through her soul, which is identical with that of man, for souls have no sex. (p. 28)

\section{Rational being}

Nico Vorster (2007:19) argues that whilst Aristotelian tradition indicates that man's image of God is directly linked to his rationality, Immanuel Kant (quoted by Vorster [2007]) related it to man's moral capacity. According to Vorster (2007), Hegel seeks it in the free will of man whilst the Roman Catholic and Eastern Orthodox traditions distinguish between the image of God in a natural and supernatural sense. The natural image indicates man's rational capacity and the supernatural image indicates a supernatural likeness to God (Vorster 2007:19).

\section{Image in relation}

For Heyns (1970:100) the image of God in man exists mainly in representation and relation. Besides Berkouwer (1957:119) and Berkhof (1969:26-31) the same opinion is held by Myles Munroe (2002:30) who says: 'Humanity cannot reveal God's image and likeness apart from a relationship with Him. God created humanity to reflect His character and personality.' In this way relation means that something of the infinite greatness and glory of God's existence and conduct is also found in human beings even in the very limited sense. Nico Vorster (2007) says:

An ontological view of the Imago Dei, however, is untenable because the likeness of man to God is thereby disentangled from the relationship between God and the human. The human becomes independent from the One according to whose image he was created. The Imago Dei is rather a relational concept that expresses the human's creational status in relation to God, his fellow man and the non-human creation. (p. 19)

In agreement with the scholars above, the author understands that the image of God in human beings can be seen clearly if people are in relation with the Creator God. Nyirongo (1994:32) supports the relational view by emphasising that human beings were created to glorify God in all areas of life (e.g. marriage, social life etc.), hence he or she should be understood in terms of the relationship with God as the Creator and Father. That is why Nyirongo (1994:107) continues to argue that since the image is violated and dented when human beings disobey God, it therefore takes salvation by Jesus Christ to bring the human being back into the original image of God.

\section{Man in natural state}

The other argument by Needleman, Bierman and Gould (1997:307) is that the image of God is the human being in his or her natural state. They went on to explain that a person comprehends what we call intellectual life (the nous) and the spiritual life (pneuma), and it is in these two realities where the true and basic human being is constituted (Needleman, Bierman and Gould 1997:307).

\section{Arguments in support of women as images of God equal to men}

An understanding of the purpose of the creation of human beings according to Mouw (1976:27) is the right direction to take when wanting to put the woman in their rightful place in society. The uniqueness of the human's creation compared to animals, is a very important point to grasp when dealing with issues relating to the human as an image of God. Douglas Waruta and Hannah Kinothi argue that women, just like men, deserve equal opportunities and rights as far as life is concerned, hence they say:

They are fully human beings entrusted with giftedness, potentials and talents. They were intended by God to be cocreators on earth in community and interdependence with other people. Women are called by God to be responsible persons, accountable to God for the stewardship of their giftedness and talents. (Waruta \& Kinothi 2000:130)

\section{Jesus Christ viewed women as equal people to men}

The fact that Jesus conversed with women, which was a defiance of contemporary Jewish customs, supports that Jesus viewed women as equal persons to men. The first example was when he spoke to a Samaritan woman at the well, which surprised his disciples in John 4:27.

Jesus' ministry was comprised of both men and women. The Gospel of Matthew confirms that although women were not counted according to the Jewish law, they were amongst 
the multitudes which followed Jesus when he taught in the mountains (Mt 15:38). Luke 8:2-3 confirms that women were part of the inner circle of His ministry because they used to walk with Him from town to town, although according to Matthew 15:38, Jewish patriarchal customs forbade the counting of women. Whilst Verhely (1984:95) argues that no self-respecting rabbi would teach a woman the law, Driver (1986:220) emphasises the same point when he acknowledges that the concrete barrier, which separated human groups from each other, (males and females) was removed by Christ's death.

\section{The way forward}

It must be prioritised that our society should be educated to treat women as human subjects, rather than as objects or possessions (McGrath 1992:215). They are fully-fledged human beings, images of God, who have the right to a peaceful life. The author is in agreement with Phiri (2003) who argues:

Issues of violence against women distort the image of God in humanity. Women need to come to the realisation that they, too, were created to reflect the image of God just as much as men are. (p. 21)

The fact that women were created in God's image means that they do not deserve to be killed by men as it is happening in the country, but they also deserve the equal safety and dignity as men do. This is the gist of the argument this article is trying to bring to the attention of the people.

The church must identify its role in helping to correct the traditions which undermine women. Its teachings about masculinity and femininity should help people to understand the equality that God expects between males and females. Churches who use theology to exploit and preclude women from ordination, must also revisit and revise their theology to accommodate women in this regard. People should realise that the church is instrumental in changing the perceptions of the people in the community because people (both Christians and non-Christians) trust that the church's view takes them in the right direction, for instance, if a non-church member dies, the next of kin come to the church to seek help to bury their beloved. This is a great opportunity that the church can use to change the thinking that women are secondary beings who can be abused and killed. Women, just like men, were created in God's image. They are human beings entrusted with giftedness, potentialities and talents. Waruta and Kinoti (2000:131) argue that they were intended by God to be cocreators on earth in community and interdependence with other people.

\section{Promoting respect for life}

The church has the duty to preach respect for life. Life comes from God and should as such be protected as a valuable gift. The Bible sees death as a result of sin. Jesus came to die to recreate God's creation by creating new life and destroying the effects of death and sin. Besides preaching respect for life, the church should also nurture a culture of respect for life by encouraging people to participate in social projects. I agree with Vorster (2007:68) when he articulates that when people learn to care by doing, they develop concern for others, and will therefore be less inclined to harmful actions towards another life. The South African Constitution (South Africa. Constitution of the Republic of South Africa 1996:Art.9.1) states: 'Everyone is equal before the law and has the right to equal protection and benefit of the law.' Novak (1986:51) is correct when saying that the first thing the church leaders and the community must do, is to accept and embrace the Bill of Rights as a way that opens reality to humankind. The reason for this is that, as the church is so influential in the community to the extent that, if it rallies behind this notion, the traditional view of women in the community would suddenly change for the better. I would like to give my own interpretation of South Africa's former Deputy President Jacob Zuma's (Zuma 2004) statement saying: 'If you teach a woman you teach the nation' by changing that to: 'if you kill a woman you also kill the nation.'

\section{Voice of the voiceless}

Liberation theologian James Cone (1982) argues that God always stood on the side of the poor and the oppressed. Whilst it is true that no one can liberate the oppressed without being against the oppressor, Cone (1982) says:

When the issue of (women dominion) is addressed to black pastors and bishops, their response is often reminiscent of the white responses to the subordination of blacks and they say women like it that way or women do not want to be pastors. (p. 122)

This statement is a clear indication that pastors and bishops who do not take the side of the women, cannot liberate women without being against the women oppressors. In that way, it can be argued that since God never withheld his punishment against the people who victimised others in any form, then liberation theology must emphasise that liberators should stand strong against oppressors. This will of course involve those engaging in the fight of being the voice of the voiceless.

The afflicted and oppressed people are sometimes unable to fight and fend for themselves; they need others who will become their voice against their oppressors. Bishops, pastors and church leaders who do not want to help the voiceless, just like the ones mentioned above by Cone, cannot play a good role in promoting the lives of other people in the community. Cone uses the example of Exodus, where God did not waste time to use any means, even the hostile actions against the Egyptian leadership, to liberate the Israelites from the Egyptian captivity. This is not a fight women should fight alone, but church leaders as well as community leaders need to stand and expose and even condemn the killings of women by their own husbands and boyfriends. This is also why Baloyi (2009:229) argues that men as oppressors must join the campaign against female domination because women may feel encouraged when they hear their former abusers denouncing what they once thought was good. 


\section{The commandment of love}

The commandment of love is central in the search for justice, including for the unjust practice of killing women for whatever reason. Ramsey (1993:2) says that the commandment of love is rooted in God's love and his governance of justice as it is expressed in the coming and work of Christ. Love stands central in Christ's attitude towards humankind. I agree with Vorster (2007:81) about the fact that love is closely related to the justice that the kingdom of God brings. God's justice means that he mends broken relationships and renews the structures and attitudes that are responsible for the broken condition. When Paul urged the Ephesian husbands (Eph 5:25): 'Husbands, love your wives just as Christ loved the church and gave his life for it', he was trying to show that it is love that can prevent family violence that also results in killing. Love can substitute the killings which are forbidden by both our government and God's law which says: 'You shall not kill' (Ex 20:13). The commandment of love extends to becoming 'each other's keepers.' When one loves their neighbour as they love themselves, it becomes very easy to become each other's keeper. This was the opinion that Pastors G.S. Moyane and S. Manganye emphasised during a radio programme entitled 'Sisumuka u vangama' - literally meaning rise and shine -when they said:

When you hear some unusual noise from your neighbour, do not be quiet about it, but rather call the police to come and investigate and by that you might have saved someone's life. It starts with us to be keepers of each other. (South African Broadcasting Corporation. Munghana Lonene 2011b)

I strongly agree with the pastors because often we are sorry after we realise that had we done something about what we heard, one or more lives could have been saved.

\section{Teaching on forgiveness and reconciliation}

Sometimes the killings of women result from the fact that some husbands never know the role of forgiveness and reconciliation whenever differences might creep into their families. Willmer (2001:28) calls forgiveness the ontology of the new creation. In the juridical sense forgiveness cannot be separated from retribution. Wiersbe (2002b:70-73) discusses the three essentials of a forgiving spirit as being kindness, a tender heart and honesty. He goes on to argue that when people cultivate an unforgiving spirit, that is usually evidence that there are other things harboured in the heart. Besides bad feelings about the other person, an unforgiving spirit speaks critically as well as slanderously about other people (Wiersbe 2002a:68). It is urgent that people are taught that an unforgiving spirit creates all kinds of problems, including seeing women as secondary beings, particularly married people who will often have some misunderstandings. Khathide (2007:140) does not only say that not forgiving tops the list of the blockages to communication, but he also states that it is like a poison that spreads throughout the body, thus gradually killing the person even without his or her full knowledge. When one spouse does not forgive the other, the communication becomes handicapped until forgiveness has taken place (Barnes \& Barnes 1994:209).
According to Wiersbe (2002b:77), human guilt tops the list of the many obstacles of reconciliation and it is advisable that all guilt should be worked out towards reconciliation to avoid any bitterness that can arise from it. To maintain good relationships with other people, particularly the opposite sex, people should learn to resolve disagreements and conflicts before it becomes hatred (Mack 1991:197). Men who kill their wives or girlfriends frequently have had unresolved problems for some time until they decide to solve or minimise those problems by killing the women.

\section{The dignity of women should be at the centre of discussions}

According to Vorster (2007):

The holistic nature of human beings implies that sexuality can never be diminished to a mere biological activity. The degrading of women into sexual objects does not only deny the wholeness of the sexual partner, but the uniqueness of that person is also lost. (p. 77)

This is why Baloyi (2010:2) argues: 'It is within viewing women as sexual objects that systematic violence is not only naturalised, but also normalised.' In thisarticle, the author tries to indicate how women's status is reduced to being mere sexual objects. This view received support from Masenya (2005:188) who argued that 1 Corinthians 7 is usually cited to remind women that they must always be available for the sexual gratification of their spouses. If the importance of women is only seen in this light, then it means that if ever men are satisfied with sexual matters then women become nothing and can be exploited in any way. According to Warunta and Kinoti (2000:131) women's dignity and worth means a right to personal integrity of their mind and of their body. Just as women have the right to their privacy, selfdetermination, self-realisation, expression of thoughts, forms and opinions, these rights have to be exercised and carried out in the context of the community, both small and large.

\section{Rehabilitation centres should be targeted by pastoral care givers}

'It is my heart's desire for every local church to be a centre of healing and transformation' - these words came from Bishop Ivan Abrahams of the Methodist church of Southern Africa (Klein 2009:9). Klein wrote the book entitled Centres of healing in response to an outcry of the churches. After reading this book one realises that it is not the primary task of the government to see that broken people receive healing, and that the church is supposed to be taking the lead in these matters. It is the responsibility of the church as well as Correctional Services with the support of the government to rehabilitate people who are traumatised and disturbed by these killings so that they can heal. Perhaps if centres of healing were in place hosted by churches, men would be prevented from killing their wives. The church should make available classes in constructive education of personal responsibility to members and non-members which could create a healthy mental attitude between sexes (Waruta \& Kinothi 2000:134). 


\section{Advocacy of separation}

It is true that divorce and separation have their own consequences, but it is not helpful to remain in unhealthy relationships which may sometimes end in one's death. That is why Waruta and Kinothi (2000:133) advocate that in an abusive relationship, separation may in some cases lead to healing in both the abused and the abuser. Most of the murders of women did not just happen on the spur of the moment without any signs showing, but they began with abuse and evolved until the husband decided to kill his wife. Therefore, it is very important that people like family elders and pastoral caregivers, who observe some growing gender-related abuse in the families, must not wait long before they report these cases to the authorities who can take steps to help. It is in these situations where, if the pastor, who is helping the family, observes that the abuse is becoming harmful and dangerous to the life of one spouse, that he or she might advise them to separate.

\section{Conclusion}

The murders of women have become endemic on South African soil. It is amongst other things related to the traditional view that women are secondary people and men should always stamp their authority on them. It has been observed that unsolved family problems also play a pivotal role towards gender-based domestic violence that may end up in the killing of wives or girlfriends. This is not what our Constitution as well as the Bible advocates. Since men and women were both created in the image of God, the issue of killing women should receive attention from both our government as well as pastoral caregivers. Besides teachings about human dignity, rehabilitation, forgiveness and love, readers should also be reminded that it is advisable that if a relationship becomes hostile to human life, separation or divorce could be a good solution. Men who abuse and even kill their wives should get the message that women are also created to reflect God's image and do not deserve to be killed.

\section{Acknowledgement Competing interests}

The author declares that he has no financial or personal relationship(s) which may have inappropriately influenced him in writing this paper.

\section{References}

Baloyi, M.E., 2009, Patriarchal structures, a hindrance to women's rights, VDM Publishing Company, Saarbrucken.

Baloyi, M.E., 2010, 'An African view of women as sexual objects as a concern for Gender Equality', Verbum et ecclesia 31(1), 1-6.

Barnes, R. \& Barnes, R., 1994, We need to talk. Opening doors of communication with your mate, Zondervan, Grand Rapids.
Berkouwer, G.C., 1957, De mens het beeld gos, Kok, Kampen.

Berkhof, H., 1969, De mens onderweg: een chistelijke mensbeschouwing, Boekencentrum, 's-Gravenhage.

Borreson, K.E., 1986, Subordination and equivalence. The nature and role of women in Augustine and Thomas Aquinas, Kok, Kampen.

Cone, J.H., 1982, My soul looks back, Abingdon Press, Nashville.

Driver, J., 1986, Understanding the atonement for the mission church, Herald Press, Pennsylvania.

Fourie, B., 2011, 'Young woman raped, stabbed after following a job lead', Pretoria News, 22 August, p. 3.

Heyns, J.A., 1970, Die nuwe mens onderweg: Oor die tien gebooie, Tafelberg, Kaapstad.

Khathide, A.G., 2007, Bone of my bones. Building marriages that work in Africa, AcadSA, Kempton Park, Johannesburg.

Khumalo, N., 2011, 'Abuse condemned', Sowetan, 27 May, p. 5.

Klein, H.L., 2009, Centres of healing, AcadSA, Kempton Park, Johannesburg.

Mack, W.A., 1991, Your family God's way. Developing and sustaining relationships in the home, R\&R Publishing, Phillipsburg.

Magagula, T., 2011, 'Dead Thembi's family wants lobola', Daily Sun, 09 June, p. 2.

Martin, L. \& Jung, P., 2002, Taking charge of the change. A holistic approach of the three phases of menopause, Delmar Thompson and Learning, Colombia.

Masenya (ngwana' Mphahlele), M., 2005, 'The Bible, HIV/AIDS and AfricanSouth African women. A Bosadi (Womanhood) perspective', Studia Historiae Acclesiasticae 1(1), 187-201.

Mashaba, S., 2011, 'ATM bombings, rape the biggest challenges', Sowetan, 9 September, p. 5.

McGrath, A.E., 1992, Bridge building: communicating Christianity effectively, Intervarsity Press, Leicester.

Mokgosi, J., 2011, 'Woman found naked and dead', Daily Sun, 23 May, p. 4.

Mouw, R.J., 1979, Politics and the biblical drama, William Eerdmans, Grand Rapids.

Munroe, M., 2002, Understanding the power and purpose of prayer: earthly license for heavenly interference, Whitaker House, New Kensington.

Needleman J., Bierman A.K. \& Gould J.A. (eds.), 1997, Religion for a new generation, Macmillan, New York.

Novak, M., 1986, Will it liberate?, Paulist Press, New Jersey.

Nyirongo, L., 1994, Gods of Africa or God of the Bible? Institute for Reformational Studies, Potchefstroom.

Phiri, I.A., 2003, 'Why does God allow our husbands to hurt us? Overcoming violence against women', Journal of Theology for Southern Africa 114, 10-30.

Rampedi, P., 2010, 'Woman killed for going on the pill', Sowetan, 24 January, p. 8.

Ramsey, P., 1993, Basic Christian ethics, John Knox Press, Westminister.

South Africa, 1996, Constitution of the Republic of South Africa, Art. 9(1).

South African Broadcasting Corporation (SABC), 2011a, Munghana Lonene, 18:3019:00, 31 May.

South African Broadcasting Corporation (SABC), 2011b, Munghana Lonene, 'Sisimuka u vangama' Sunday morning, 06:00-07:30, 06 November.

South African Government Information, 2011, 'The Commission for Gender Equality (CGE) condems the brutal killing of Noxolo Nogwaza', viewed n.d., from http:// www.info.gov.za/speech/DynamicAction?pageid=461\&sid=18031\& $\mathrm{tid}=32623$

South African Press Association, 2011, 'Order for Dewani to be tried in SA', Sowetan, 28 September, p. 5.

Verhely, A., 1984, The great reversal. Ethics and the New Testament words, William Eerdmans, Grand Rapids.

Vorster, N., 2007, Restoring human dignity in South Africa, Potchefstroom theological Publications, Potchefstroom.

Waruta, D.W. \& Kinoti, H.W., 2000, Pastoral care in African Christianity. Challenging Essays in Pastoral Theology, Abingdon Press, Nairobi.

'Where am I wrong when I beat my own wife?' City Press, 18 February, 2007, p. 10.

Wiersbe, W.W., 2002a, Caring people. Learning to live with and help one another, Baker, Grand Rapids.

Wiersbe, W.W., 2002b, Key words of the Christian Life. Understanding and applying their meanings, Baker, Grand Rapids.

Willmer, H., 2001, Jesus Christ the Forgiven. Christology, Atonement and Forgiveness. Forgiveness in Truth Explorations in Contemporary Theology, T \& T Clark, Edinburgh.

Zuma, J., 2004, Statement made , SABC2 News, 19:30, 31 August. 